\title{
Both Traditional and Semi-bush Tropical Pumpkin Can Be Intercropped with Beans or Cowpeas
}

Patrick Chesney ${ }^{1}$ and Linda Wessel-Beaver ${ }^{2}$

University of Puerto Rico, College of Agricultural Sciences, P.O. Box 9030, Mayagüez, PR 00681-9030

Donald N. Maynard ${ }^{3}$

Gulf Coast Research and Education Center, University of Florida, 5007 60th Street East, Bradenton, FL 34203

Additional index words. Cucurbita moschata, Phaseolus vulgaris, Vigna unguiculata, cucurbits, bush growth habit, intercropping, green-shelled beans

Abstract. Most cultivars of tropical pumpkin (Cucurbita moschata Duchesne) are large, trailing plants. New semi-bush (SB) genotypes need to be tested against traditional long vine (LV) types. Both types of pumpkin have large amounts of interplant space during the early stages of growth that might allow for the planting of an intercrop. To test this hypothesis, as well as the performance of tropical pumpkins of varying growth habit, double rows of beans (Phaseolus vulgaris L.) or cowpeas [Vigna unguiculata (L.) Walp.] were intercropped between rows of SB or traditional LV tropical pumpkin in Spring and Fall 1993 in Lajas and Isabela, Puerto Rico. In general, interactions between intercrop treatment and pumpkin genotype were not significant. At its maximum percentage cover (MC) the LV genotype covered, or nearly covered, the entire plot while the SB genotype covered $50 \%$ of the plot or less. The SB pumpkin was harvested 5 to 27 days earlier than the LV type. Yield was two to 12 times greater, and average fruit size three to six times greater in the latter. Planting of an intercrop did not reduce pumpkin yield. Green-shelled yields of intercropped legumes averaged $\approx 700 \mathrm{~kg} \cdot \mathrm{ha}^{-1}$. Genotype of the pumpkin maincrop did not affect legume green-shelled yields in Lajas. In Isabela, legume green-shelled yields were $50 \%$ higher in SB than in LV pumpkin plots. Legume dry grain yields were greatly reduced in $\mathrm{LV}$ compared to SB plots. Intercropping of tropical pumpkin with a short season legume that can be harvested green-shelled is an efficient intercropping system that offers additional yield from the legume without sacrificing yield from the pumpkin maincrop. Both SB and LV pumpkins can be used in an intercrop system, but pumpkin yields were much greater with the $L V$ genotype.

In Puerto Rico, Florida, and other areas of the Caribbean Basin, tropical pumpkin is commercially planted in monoculture. Tropical pumpkin cultivars and landraces used in commercial plantings have vines that may reach $15 \mathrm{~m}$ in length, requiring wide planting distances. In Puerto Rico, the trend has been to decrease the within-row planting distance while increasing the space between rows to 3 to $4 \mathrm{~m}$ to allow mechanical cultivation during

Received for publication 30 Oct. 2002. Accepted for publication 28 Sept. 2003. This paper is a portion of a thesis submitted by the senior author. The tropical pumpkin genotypes used in this research were developed at the Univ. of Florida by Gary W. Elmstrom. We thank Obed Román for his technical assistance. This research was supported in part by the U.S. Dept. of Agriculture under CSRS (now CSREES) Special Grants (Nos. 91-34135-6165 and 91-34135-6172) managed by the Caribbean Basin Advisory Group (CBAG, now TSTAR) and the Puerto Rico Agricultural Experiment Station.

${ }^{1}$ Graduate student, Dept. of Horticulture. Current address: D 39, National Agricultural Research Institute, Mon Repos, East Coast Demerara, Guyana, South America.

${ }^{2}$ Professor, Dept. of Agronomy and Soils, to whom reprint requests should be addressed. Email address: lwesselbeaver@yahoo.com.

${ }^{3}$ Professor. the first few weeks following planting. Rows fill in 8 to 10 weeks after planting. Recently, various semi-bush (SB) tropical pumpkin lines and hybrids have been developed (Maynard et al., 2002), but limited testing of these new types have been carried out. These pumpkins have a compact growth habit, although some may become viney at maturity. When wide row spacings are used, both types of pumpkins have an initial period when the canopy is open. A short-season crop, such as a determinate habit bean or cowpea, intercropped with the pumpkin maincrop, could potentially contribute additional income without reducing that from the pumpkin maincrop. These legumes can be harvested at physiological maturity, a class of legume call "green-shelled." If the legume can be harvested before the pumpkin rows fill in, the morphophysiological differences between pumpkin and legume contribute toward temporal and spatial complementarity. Moreover, early harvest of the legume has the potential effect of contributing residual nitrogen to the pumpkin that can optimize nitrogen use as it coincidentally changes growth phenology at the time of legume harvest.

The population density of an intercrop is critical to the attainment of yield similar or superior to the corresponding sole crops. In
Arizona, Itulya (1982) found that the harvest index of mung bean \{Phaseolus aureus Roxb. [syn. Vigna radiata $(\mathrm{L})]\}$ and $P$. vulgaris was not influenced by intercropping or by increasing the plant population of summer squash $(C$. pepo L.). However, in Kenya, where bean-based intercropping is common, Itulya and Oebker (1989) found that $C$. pepo planted at intrarow spacings below $100 \mathrm{~cm}$ significantly reduced the yield of $P$. vulgaris and $V$. radiata $(\mathrm{L})$ Wilczek. Seed and biomass yields of legumes were reduced when intercropped with high densities of C. pepo (Itulya, 1982). In many parts of the American tropics the bean-squash-corn complex used since pre-Colombian times is still a common cultural practice (Whitaker, 1981). In Puerto Rico, beans are often seen intercropped with bananas, plantains, or various root crops But even though tropical pumpkin is the second most important vegetable on the island (Alamo, 1992), no work has been carried out on intercropping systems with this crop, nor reported from other areas of the Caribbean.

The objective of this study was to compare the performance of an SB tropical pumpkin to a traditional long vine (LV) type, both as a sole crop and as the maincrop in a bean or cowpea intercrop system. A second objective was to determine if a harvestable yield of bean or cowpea, either as green-shelled or dry grain, could be produced when intercropped with pumpkin.

\section{Materials and Methods}

Studies were conducted in Puerto Rico on a clayey, kaolinitic, and isohyperthermic Oxisol (Isabela, spring and fall), on a fine, montmorillonitic isohyperthermic Vertisol (Lajas, spring) and on a fine-loamy, mixed isohyperthermic Mollisol (Lajas, fall). Land preparation consisted of disc plowing and two harrowings.

Combinations of two tropical pumpkin types (LV and SB) and three intercrop treatments (bean, cowpea, or no intercrop) were direct seeded in two locations on three dates (on 22 Feb. 1993 in Lajas, 3 Sept. 1993 in Isabela, and 7 Oct. 1993 in Lajas). The LV genotype, PRB-150, originated from Puerto Rico. The SB genotype was either I25 $\times$ I21 (Lajas and Isabela, spring), (I25 $\times$ I21)F3 (Lajas, fall), or I25 (Isabela, fall), all originating from Florida. Slightly different SB genotypes were used in each planting because of limited availability of seed. The bean cultivar was 'Dorado', the cowpea cultivar was 'Gorda.' In each environment, the 2 pumpkin genotypes $\times 3$ intercrops factorial combination of treatments was replicated three (Lajas) or five (Isabela) times in a randomized complete-block design. Plots consisted of either three rows (Isabela) or 0.9-m-high raised beds (Lajas), $1.92 \mathrm{~m}$ long and spaced $1.82 \mathrm{~m}$ center to center. Twelve pumpkin plants per row (bed), at an in-row spacing of $0.91 \mathrm{~m}$, were planted in the outside rows. The center row of each plot was either left unplanted (no intercrop), or planted in either beans or cowpeas in a double "row," spaced $0.25 \mathrm{~m}$ from each side of the center of the plot. Beans and cowpeas were planted at an in-row 
spacing of $0.08 \mathrm{~m}$, a planting density typical of the region. Pumpkin plants were thinned to one per hill, leaving a population of 3005 plant per hectare, typical of commercial plantings in the Caribbean. A drip irrigation line was used in each pumpkin row and between the double row of the legume intercrop.

A single application of $87 \mathrm{~kg} \cdot \mathrm{ha}^{-1} \mathrm{~N}, 72$ $\mathrm{kg} \cdot \mathrm{ha}^{-1} \mathrm{P}$, and $37.5 \mathrm{~kg} \cdot \mathrm{ha}^{-1} \mathrm{~K}$ was made to the legume intercrops $7 \mathrm{~d}$ after planting (DAP). Pumpkin plantings received two side dressings of N-P-K: $50 \mathrm{~kg} \cdot \mathrm{ha}^{-1} \mathrm{~N}, 21.5 \mathrm{~kg} \cdot \mathrm{ha}^{-1} \mathrm{P}$, and 41 $\mathrm{kg} \cdot \mathrm{ha}^{-1} \mathrm{~K}$ at seven DAP, and $100 \mathrm{~kg} \cdot \mathrm{ha}^{-1} \mathrm{~N}, 43$ $\mathrm{kg} \cdot \mathrm{ha}^{-1} \mathrm{P}$, and $83 \mathrm{~kg} \cdot \mathrm{ha}^{-1} \mathrm{~K}$ at floral initiation. Lajas fall pumpkins received similar total amounts of N-P-K in biweekly applications of liquid fertilizer through irrigation drip lines Insects were controlled with endosulfan, diazinon, methomyl, and Baccilus thuringiensis Berliner (Bt). Weed control was accomplished by mechanical cultivation at $21 \mathrm{DAP}$, followed by hand hoeing at 28 to 35 DAP.

Pumpkin canopy cover was estimated weekly from 28 DAP by using a chart made with grid paper that represented $20 \%, 40 \%$, $60 \%$, and $80 \%$ cover. Maximum cover (MC) (measured as percentage of plot area) and days from planting to MC were measured. Days to flower (DTF) for pumpkin was determined as number of days elapsed from planting to the appearance of pistillate flowers on half of the plants in the plot. Pumpkin fruits were harvested as they matured, $\approx 50 \mathrm{~d}$ after anthesis (Unander and Varela-Ramírez, 1988). Total fruit weight (yield) and number of fruit per plot were measured and used to determine average fruit weight. Harvest index (HI) of the pumpkin genotypes, calculated as the ratio of fruit yield : aboveground biomass, was measured by bulking plant samples across plots within a pumpkin genotype, and thus could not be statistically analyzed. Bean and cowpea intercrops were harvested at physiological maturity (greenshelled), determined when $10 \%$ to $20 \%$ of the pods changed color from green to yellow as described by Román-Hernández (1991), and at grain maturity. At the green-shelled stage, whole plants were removed from an inner 3.6-m-length of an intercrop row (double row), counted and weighed. Green pods were removed and weighed. The weight of beans or cowpeas shelled from a 1000-g sample of pods was used to estimate whole-plot greenshelled yields. At full maturity, dry grain yield was determined by threshing and weighing all grain from another $3.6 \mathrm{~m}$ of the remaining intercrop row.

\section{Results and Discussion}

Results of Bartlett's test of homogeneity of variance disallowed combined analyses over the three plantings for all variables except MC. Consequently, results and discussion of all variables are based on individual environments since no statistical tests could be made of apparent differences between environments. With one exception (discussed below), no genotype $x$ intercrop interactions were observed. Thus, the relative performance of $\mathrm{LV}$ compared to the SB genotypes was generally unaffected by intercrop treatment.

Pumpkin growth and flowering. In the Lajas spring planting the SB genotype reached MC nearly 3 weeks earlier than the LV type (Table 1). However, MC in LV plots was more than four times that in SB plots. SB plots flowered $\approx 27 \mathrm{~d}$ earlier than LV plots. The type of intercrop planted with the pumpkin maincrop did not affect days to MC, MC, or DTF.

In the Isabela fall planting, the genotype $x$ intercrop interaction was significant for days to MC. In SB plots the number of days to MC did not vary with intercrop (data not shown). In contrast, the LV genotype reached MC nearly a week earlier (at 7 weeks) in plots with no intercrop compared to those with beans or cowpeas (data not shown). SB plots in this planting covered nearly twice as much plot area (MC) compared to SB plots in the spring Lajas planting, but MC of the LV genotype was still two and a half times more than that of SB type. SB plots again flowered much earlier than LV plots. Type of intercrop did not affect the MC of the pumpkin maincrop. Pumpkins planted together with an intercrop produced more vegetative growth (MC) than plots with no intercrop, indicating that the legumes may have contributed nutritionally to the pumpkin maincrop. DTF was unaffected by intercrop.

In the Lajas fall planting, both SB and LV genotypes reached MC in 7 to 8 weeks (Table 1). As in the spring Lajas and fall Isabela plantings, MC of the LV type was significantly greater than that in SB plots. MC was greater in pumpkin plots with bean than in those with cowpea. However, type of intercrop had no effect on days to MC. DTF was not determined in this planting.

Although the number of days to $\mathrm{MC}$ varied among the three plantings, the LV genotype consistently covered, or nearly covered, the entire plot whereas the SB type covered about half or less of the plot. Canopy growth continued in the LV plots after MC was reached, but semi-bush plants began to senesce soon after attaining MC. The SB pumpkin genotypes consistently flowered at $\approx 36$ DAP, whereas the LV genotype flowered $\approx 25 \mathrm{~d}$ later. The SB genotypes were developed in Florida from crosses between temperate and tropical types of $C$. moschata while the LV genotype is a typical tropical cultivar developed in Puerto Rico. Wessel-Beaver and Varela (1991) and Wessel-Beaver and Velázquez (1991) also found that temperate pumpkin varieties flowered and set fruit earlier than tropical varieties. During the fall plantings, pistillate flowers in SB plots appeared 1 to 2 weeks before pollen was available from staminate flowers, and this may have reduced fruit production. The first harvest of the SB genotype occurred 5 to $27 \mathrm{~d}$ earlier than the LV type (Table 2). We did not observe any effects of intercropping on pumpkin maturity. Within a particular growth habit type, both intercropped and nonintercropped pumpkins were harvested on the same days. The green-shelled legume intercrops were harvested 14 to $21 \mathrm{~d}$ before the SB type and 26 to $44 \mathrm{~d}$ before the first harvest of the LV genotype. At those dates the legumes could be

Table 1. Means, F tests, single degree of freedom contrasts, and coefficients of variation for days from planting to maximum cover (MC), MC (percentage of total plot area), and days from planting to flowering (DTF) of pumpkin genotypes planted in Lajas and Isabela, Puerto Rico.

\begin{tabular}{|c|c|c|c|c|c|c|c|c|}
\hline \multirow[b]{2}{*}{ Treatments } & \multicolumn{3}{|c|}{ Lajas, spring } & \multicolumn{3}{|c|}{ Isabela, fall } & \multicolumn{2}{|c|}{ Lajas, fall ${ }^{2}$} \\
\hline & $\begin{array}{c}\text { Days to } \\
\text { MC }\end{array}$ & $\mathrm{MC}(\%)$ & DTF & $\begin{array}{c}\text { Days to } \\
\text { MC }\end{array}$ & $\operatorname{MC}(\%)$ & DTF & $\begin{array}{c}\text { Days to } \\
\text { MC }\end{array}$ & $\mathrm{MC}(\%)$ \\
\hline \multicolumn{9}{|l|}{ Pumpkin genotype $(\mathrm{G})^{y}$} \\
\hline Long vine & 78.3 & 100.0 & 64.4 & 56.5 & 100.0 & 56.9 & 56.0 & 92.7 \\
\hline Semi-bush & 58.0 & 23.5 & 37.3 & 60.6 & 41.3 & 35.0 & 49.7 & 56.6 \\
\hline Significance & $* *$ & $* *$ & $* *$ & $*$ & $* *$ & $* *$ & NS & $* *$ \\
\hline \multicolumn{9}{|l|}{ Intercrop $(I)^{x}$} \\
\hline No intercrop & 66.8 & 63.6 & 51.5 & 56.7 & 68.0 & 45.5 & 54.8 & 73.3 \\
\hline With bean & 69.5 & 60.0 & 49.6 & 60.2 & 72.0 & 46.2 & 53.6 & 79.2 \\
\hline With cowpea & 68.2 & 61.6 & 51.5 & 58.8 & 72.0 & 46.2 & 50.2 & 71.6 \\
\hline \multicolumn{9}{|l|}{ Contrasts } \\
\hline No intercrop vs. intercrop & NS & NS & NS & NS & $*$ & NS & NS & NS \\
\hline Bean vs. cowpea & NS & NS & NS & NS & NS & NS & NS & $*$ \\
\hline $\mathrm{G} \times \mathrm{I}$ & NS & NS & NS & $*$ & NS & NS & NS & NS \\
\hline $\mathrm{CV}$ & 6.2 & 8.6 & 3.8 & 9.0 & 7.6 & 4.0 & 12.2 & 5.9 \\
\hline
\end{tabular}

${ }^{2}$ Days to flowering (DTF) not determined in this environment.

yumpkin means for each genotype were averaged over three intercrop treatment levels. Long vine genotype = PR150; semi-bush genotype = I25 × I21 (Lajas, spring); I25 (Isabela, fall); (I25 × I21)F3 (Lajas, fall).

${ }^{x}$ Pumpkin means for each intercrop treatment were averaged over two pumpkin genotypes.

Ns,****Nonsignificant or significant at $P \leq 0.05$ or 0.01 , respectively. 
Table 2. Days from planting to harvest of legume intercrops and pumpkin maincrops in spring and fall plantings in Isabela and Lajas, Puerto Rico.

\begin{tabular}{|c|c|c|c|c|c|c|c|c|}
\hline \multirow[b]{3}{*}{ Environment } & \multicolumn{4}{|c|}{ Intercrop } & \multicolumn{4}{|c|}{ Pumpkin maincrop ${ }^{z}$} \\
\hline & \multicolumn{2}{|c|}{ Cowpea } & \multicolumn{2}{|c|}{ Bean } & \multicolumn{2}{|c|}{ Long vine } & \multicolumn{2}{|c|}{ Semi-bush } \\
\hline & $\begin{array}{c}\text { Green-shell } \\
\text { harvest }\end{array}$ & $\begin{array}{c}\text { Dry grain } \\
\text { harvest }\end{array}$ & $\begin{array}{c}\text { Green-shell } \\
\text { harvest }\end{array}$ & $\begin{array}{c}\text { Dry grain } \\
\text { harvest }\end{array}$ & $\begin{array}{c}\text { First } \\
\text { harvest }\end{array}$ & $\begin{array}{c}\text { Final } \\
\text { harvest }\end{array}$ & $\begin{array}{c}\text { First } \\
\text { harvest }\end{array}$ & $\begin{array}{c}\text { Final } \\
\text { harvest }\end{array}$ \\
\hline Lajas, spring & 64 & 81 & 66 & 81 & 108 & 134 & 81 & 81 \\
\hline Isabela, fall & 59 & 70 & 63 & 74 & 85 & 111 & 80 & 80 \\
\hline Lajas, fall & 70 & $\mathrm{ND}^{\mathrm{y}}$ & 77 & ND & 105 & 133 & 84 & 133 \\
\hline
\end{tabular}

${ }^{2}$ Long vine genotype = PR150; semi-bush genotype = I25 × I21 (Lajas, spring); I25 (Isabela, fall); (I25 × I21)F3 (Lajas, fall).

${ }^{\mathrm{N} D}=$ no data. Dry grain legume harvest lost under pumpkin canopy.

Table 3. Means, F tests, single-degree-of-freedom contrasts and coefficients of variation for yield, number of fruit and average fruit weight of the pumpkin maincrop planted in Lajas and Isabela, Puerto Rico.

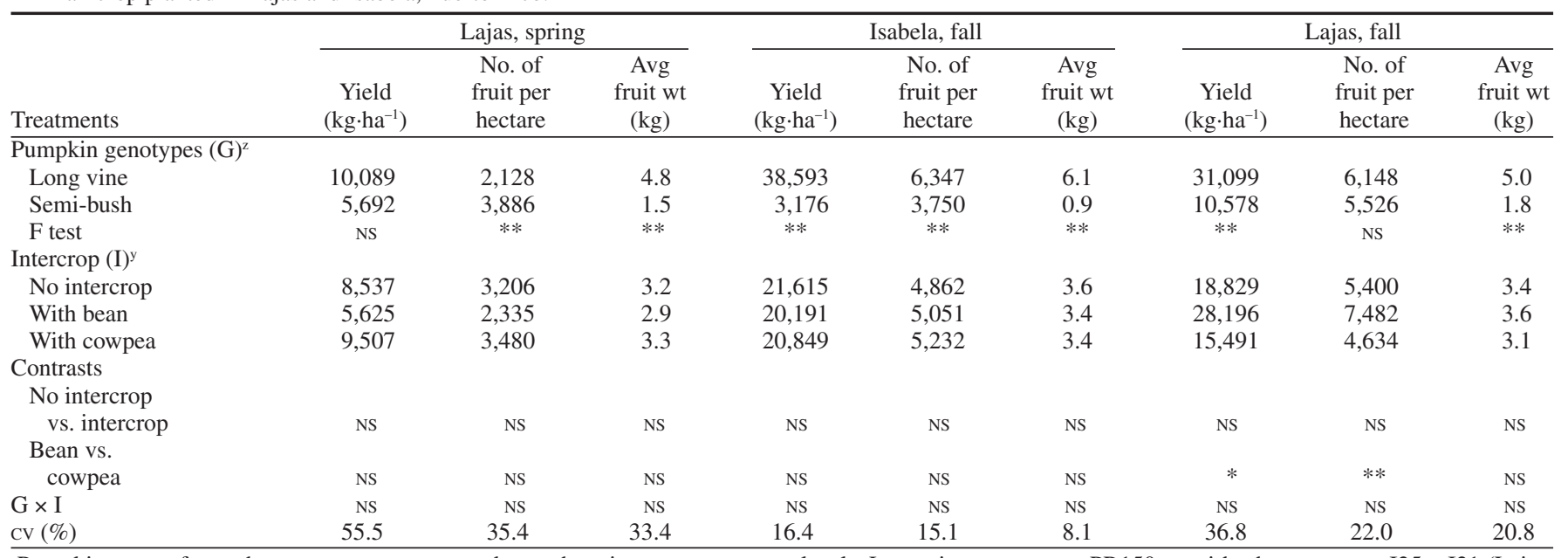

${ }^{2}$ Pumpkin means for each genotype were averaged over three intercrop treatment levels. Long vine genotype $=$ PR150; semi-bush genotype $=$ I25 $\times$ I21 (Lajas, spring); I25 (Isabela, fall); (I25 × I21)F3 (Lajas, fall).

yPumpkin means for each intercrop treatment were averaged over two pumpkin genotypes.

Ns,*,**Nonsignificant or significant at $P \leq 0.05$ or 0.01 , respectively.

easily accessed for harvesting without much trampling of the pumpkin vines.

Pumpkin yield and yield components. In the Lajas spring planting, long and SB pumpkin yields were not different (Table 3). The SB genotype produced more fruit than the LV type, but average fruit weight was greater in the latter. The presence of an intercrop did not affect pumpkin yield, number of fruit, or average fruit weight.

In the Isabela fall planting, the LV genotype was superior to the SB type for yield, number of fruit, and fruit weight (Table 3). The LV type produced more than 10 times the yield and nearly twice as many fruit as the SB type. LV fruits were about six times heavier than those of the SB genotype. Intercrop had no effect on pumpkin yield or its components.

In the Lajas fall planting, the long-vine genotype again produced higher yield and fruit weight than the SB type, but number of fruit was not significantly different between genotypes (Table 3). A higher pumpkin yield and more fruits were produced in bean than in cowpea plots. This agrees with the greater MC observed in bean plots (Table 1). Yield and weight of pumpkins were not reduced in intercrop plots compared to nonintercrop plots.

Commercial pumpkin yields in Puerto Rico are variable. Average yields reported by Alamo (1992) varied from 8,000 to $15,000 \mathrm{~kg} \cdot \mathrm{ha}^{-1}$ depending on location. In our plantings, the LV genotype, PRB-150, exceeded these averages in two of three trials, and yielded three to 12 times as much as the SB pumpkin. Wessel-Beaver and Varela (1991) also found that tropical pumpkin genotypes yielded more than their temperate, usually shorter vine, counterparts.

Over the three plantings, number of fruits ranged from 2100 to $6300 /$ ha or 0.7 to 2.1 fruits per plant. Although no statistical comparisons can be made, fewer fruits were produced in the spring planting than in the fall plantings. Average fruit weight was similar in all three environments. The LV genotype produced very large fruit (4.8 to $6.1 \mathrm{~kg}$ ), whereas the fruit of SB types was small (0.9 to $1.8 \mathrm{~kg}$ ). Compared to the two Lajas plantings, Isabela had a higher mean LV fruit weight and a lower mean SB fruit weight. Wessel-Beaver and Varela (1991) found that the average fruit weight of PRB-150, the LV genotype used in this study, was 4.2 $\mathrm{kg}$ compared to 0.3 to $0.5 \mathrm{~kg}$ for temperate short-vine varieties.

Although no statistical test is possible because data were combined across plots (reps), $70 \%$ of the biological yield (harvest index) in the Isabela fall planting was partitioned into fruit production in the SB genotype, compared to only $\approx 50 \%$ in the LV type (data not shown), suggesting that although the SB genotype was lower yielding, it was biologically more efficient than the LV genotype. Visual inspection in the other two trials also supports this conclusion.

Consumer preference for orange-yellow to dark orange pulp color and globe or flat shaped fruit described by Carbonell et al. (1990) were characteristic of fruits of PRB-150 but not of the SB genotype. The inclusion of these desirable fruit characteristics may increase the acceptability of SB cultivars of tropical pumpkin Recent efforts in Florida and Puerto Rico have increased fruit size, yield, and quality of SB cultivars and hybrids (Maynard et al., 2002). We have also conducted studies that suggest that SB yields can be increased by increasing planting density (data not shown).

Legume intercrop yields. There were differences in green-shelled yields of bean and cowpea intercrops in the Lajas spring and Isabela fall plantings, but not in the fall in Lajas (Table 4). In the Lajas spring planting, bean yield was less than half that of cowpea. In the Isabela fall planting, by contrast, bean yield was superior to cowpea yield. For legume green-shelled yield, the interaction of intercrop with genotype was nonsignificant. Román-Hernández (1991) found that beans planted in Puerto Rico produced the highest green-shelled yields from October to December. Monar-Benavides (1992) reported that cowpea yield was greater when planting in January than in May.

Legume yields in SB and LV plots were different only in the Lajas fall planting (Table 4). A higher legume green-shelled yield was observed in SB plots than in LV plots.

Since pumpkin yields were not reduced by the presence of an intercrop, the legume green-shelled yield could provide additional income to growers of a pumpkin maincrop. 
Table 4. Means and F tests for green-shelled yield of bean and cowpea intercrops grown with long or short vine pumpkins in Lajas and Isabela, Puerto Rico.

\begin{tabular}{lrrc}
\hline & \multicolumn{3}{c}{ Legume green-shelled yield $\left(\mathrm{kg} \cdot \mathrm{ha}^{-1}\right)$} \\
\cline { 2 - 4 } Treatments & Lajas, spring & Isabela, fall & Lajas, fall \\
\hline Intercrop $(\mathrm{I})^{\mathrm{z}}$ & 452 & 1,179 & 388 \\
$\quad$ Bean & 1073 & 870 & 476 \\
Cowpea & 763 & 1025 & 432 \\
Mean & $* *$ & $* *$ & $\mathrm{NS}$ \\
F test & & & 361 \\
Pumpkin genotype $(\mathrm{G})^{\mathrm{y}}$ & 768 & 836 & 503 \\
With long vine & 756 & 1213 & $\mathrm{NS}$ \\
With semi-bush & $\mathrm{NS}$ & $* *$ & $\mathrm{NS}$ \\
F test & $\mathrm{NS}$ & $\mathrm{NS}$ & 44.02 \\
I $\times$ G & 9.2 & 10.2 & \\
$\mathrm{CV}(\%)$ & & & \\
\hline
\end{tabular}

${ }^{2}$ Each legume mean was averaged over two pumpkin genotypes.

yLegume means for each pumpkin genotype treatment level were averaged over both beans and cowpeas. Long vine genotype $=$ PR150; semi-bush genotype $=$ I25 $\times$ I21 (Lajas, spring); I25 (Isabela, fall); (I25 × I21)F3 (Lajas, fall).

ss, ${ }^{* *}$ Nonsignificant or significant at $P \leq 0.01$, respectively.

Green-shelled beans are a very high-value crop in the Caribbean. Legume green-shelled yield exceeded dry grain yield (data not reported here) by more than $60 \%$. Badillo-Feliciano et al. (1985) found that bean green-shelled yield was $70 \%$ more than bean grain yield in plantings in Puerto Rico. In Puerto Rico, the retail value of green-shelled beans or cowpeas is at least 10 times that of dry grain (J.S. Beaver, personal communication). Legumes were harvested green-shelled $\approx 15 \mathrm{~d}$ earlier than as dry grain (Table 2). The pumpkin-legume intercropping system either did not allow for the harvest of dry legume grain, or produced grain of poor quality. These effects were more pronounced in plots with the LV genotype as the pumpkin maincrop. In these plots especially, the pumpkin $\mathrm{MC}$ was reached before the legumes were ready for dry grain harvest. The bean intercrop in particular was completely lost under the pumpkin canopy.

Compared to the nonintercropped plots, the presence of the legume in the intercropped plots was observed to be a determent to weed growth in the area between pumpkin rows. In Puerto Rico, both pumpkins and beans are often hand weeded. However, if chemical herbicides would be used, the presence of two different crop species would complicate weed control.

Conclusion. SB tropical pumpkin types may need different cultural practices, especially greater planting densities, to achieve yield levels of traditional LV types. Continued breeding efforts will also likely result in improve SB cultivars. Both types of tropical pumpkin allowed for harvest of green-shelled beans or cowpeas before the pumpkin maincrop vines grew over the intercrop rows. Pumpkin yields were not reduced with the inclusion of an intercrop. Tropical pumpkin intercropped with either bean or cowpea exhibited system complementarity, both temporally and spatially, thus offering growers a potential additional source of income. What additional costs may be incurred with intercropping was not considered in this research, but merits future study.

\section{Literature Cited}

Alamo, C.I. 1992. Empresas Agrícolas de Puerto Rico. Rpt. Agr. Expt. Sta., Univ. P.R., Río Piedras.

Badillo-Feliciano, J., I. Reyes-Soto, and J.S. Beaver. 1985. A comparison of yields of common beans at physiological and harvest maturity. J. Agr. Univ. P.R. 69(1):19-24.

Carbonell, M.E., L. Wessel-Beaver, F. Varela, and B. Luciano. 1990. Pumpkin (Cucurbita moschata) breeding priorities based on a survey among Puerto Rican consumers. J. Agr. Univ. P.R. 74(3):229-236.

Itulya, F.M. 1982. The influence of intercropping on growth and yield of summer squash (Cucurbita pepo L.), mung bean (Phaseolus aureus Roxb.) and pinto beans (Phaseolus vulgaris L.) Diss. Abstr. Intr., B (1980). 42(2):424. [Field Crops Abstr. 35(11):9044; 1982].

Itulya, F.M. and N.F. Oebker. 1989. Effects of intercropping and population on yield of mung bean (Vigna radiata $(\mathrm{L}$.) Wilczek), pinto bean (Phaseolus vulgaris L.) and summer squash (Cucurbita pepo L.). E.Afr.Agr. For. J. 51(2):93-100. [Hort. Abstr. 59(1):275; 1989].

Maynard, D.N., G.W. Elmstrom, S.T. Talcott, and R.B. Carle. 2002. 'El Dorado' and 'La Estrella': Compact plant tropical pumpkin hybrids. HortScience 37:831-833.

Monar-Benavides, C.M. 1992. Efecto de épocas de siembra y densidades de maíz (Zea mays L.) en el sistema intercalado con caupí (Vigna unguiculata Walp.). MS thesis. Univ. PP.R., Mayagüez Campus, Mayagüez.

Román-Hernández, O. 1991. Efectos de época de siembra y etapa de cosecha en el comportamiento de cinco genotipos de habichuelas (Phaseolus vulgaris L.). MS thesis. Univ. PP.R., Mayagüez Campus, Mayagüez.

Unander, D.W. and F. Varela-Ramírez. 1988. Selection of pulp color and thickness in calabaza. HortScience 23:755-757.

Wessel-Beaver, L. and F. Varela. 1991. Performance of parents and progenies in Caribbean $\times$ temperate crosses of Cucurbita moschata. HortScience 26:740.

Wessel-Beaver, L. and L. Velázquez. 1991. Flowering and fruit set in tropical versus temperate germplasm of Cucurbita moschata, p. 767. vol. 26. Proc. XXVI Annu. Mtg. Caribbean Food Crops Soc., 29 July-3 Aug., 1990.

Whitaker,T.W. 1981.Archeological cucurbits. Econ. Bot. 35(4):460-466. 